\title{
Identification and Management of Intravagal Parathyroid Adenoma
}

\author{
Timothy M. Pawlik, M.D., M.P.H., ${ }^{1}$ Melanie Richards, M.D., ${ }^{1}$ Thomas J. Giordano, M.D., Ph.D., ${ }^{2}$ \\ Richard Burney, M.D., ${ }^{1}$ Norman Thompson, M.D. ${ }^{1}$ \\ ${ }^{1}$ Section of Endocrine Surgery, Department of Surgery, University of Michigan Medical Center, 2920 Taubman Health Care Center, 1500 E. \\ Medical Center Drive, Ann Arbor, Michigan 48109, USA \\ ${ }^{2}$ Department of Pathology, University of Michigan Medical Center, 2920 Taubman Health Care Center, 1500 E. Medical Center Drive, Ann \\ Arbor, Michigan 48109, USA
}

\begin{abstract}
Intravagal parathyroid adenomas are rare, with only three cases reported in the English literature. The objective of this report is to describe two additional patients with hyperfunctioning parathyroid glands found within the vagus nerve and to define the anatomy of this finding. Both patients presented with a history of persistent hyperparathyroidism despite multiple therapeutic interventions. A high cervical localization was established in both cases by selective venous sampling. In each patient successful removal of the intravagal parathyroid gland was achieved with subsequent resolution of calcium and parathyroid levels. Each adenoma was located within the vagus nerve below the level of the carotid bifurcation and was enucleated without sacrificing the vagus nerve. In our cases and those reported previously, the parathyroid glands were supernumerary, representing parathyroid tissue embryologically derived from the third branchial pouch. Exploration for hyperparathyroidism requires a complete, meticulous surgical dissection to identify all parathyroid glands and to search for possible accessory tissue in selected cases. Our experience and a review of the literature serve to emphasize that, although rare, intravagal parathyroid adenomas do occur. Examination of the vagus nerve should therefore be strongly considered when four normal glands are found, as intravagal adenomas appear to represent accessory ectopically located parathyroid tissue.
\end{abstract}

The tendency of parathyroid tissue to locate in obscure sites is well recognized. Because parathyroid glands can be found anywhere from the angle of the mandible to the middle mediastinum, successful exploration for hyperfunctioning parathyroid glands depends on a clear understanding of the locations in which parathyroid tissue can be found and a systematic search for all abnormal parathyroid tissue [1]. A superior gland, for example, not found in the usual location is most likely to be found in the tracheoesophageal groove or lateral or posterior to the esophagus. A missing inferior gland is most likely to be found in the thymus, in the lower pole of the thyroid, or in the carotid sheath at the level of the carotid bifurcation.

In some patients, however, when all these possibilities have been exhausted, primary hyperparathyroidism persists because of an ectopic or supernumerary gland in a highly unusual anatomic site. Parathyroid tissue has been identified in a variety of locations, including the lateral neck, ectopic thymic tissue, near the hyoid bone, or near a submandibular salivary gland [2-4]. The

Correspondence to: T.M. Pawlik, M.D., M.P.H., e-mail: tpawlik@umich.edu parathyroids in these locations are considered undescended inferior glands. More recently, hypercellular parathyroid adenomas thought to be derived from undescended superior glands were reported in the pharyngeal wall at the level of the piriform sinus [5].

Intravagal parathyroid adenomas are rare, with only three cases reported in the English-language literature [6-8]. We describe here two additional patients with enlarged hyperfunctioning parathyroid glands in the vagus nerve. In addition, we describe an embryologic explanation for the presence of intravagal parathyroid tissue. The results indicate that intravagal adenomas, although rare, do occur and invariably represent supernumerary tissue near the level of the carotid bifurcation.

\section{Patient 1}

A 48-year-old man was referred to the University of Michigan Medical Center for evaluation of persistent tertiary hyperparathyroidism in 1981. The patient had a history of renal failure secondary to medullary cystic kidney disease and had required hemodialysis since 1974. A cadaveric kidney transplant performed in 1975 failed after 13 months. In 1981 he developed symptoms of fatigue, crampy abdominal pain, weakness, and bone pain. His calcium level was $11.0 \mathrm{mg} / \mathrm{dl}(8.8-10.4 \mathrm{mg} / \mathrm{dl})$ and his C-terminal parathyroid hormone (PTH) level was $>1000 \mathrm{pg} / \mathrm{ml}(10-65 \mathrm{pg} / \mathrm{ml})$. At parathyroid exploration, four parathyroids were identified in normal locations. A three and three-quarter gland parathyroidectomy was carried out, sparing only one-quarter of the left inferior parathyroid gland. The patient's calcium level normalized, and his symptoms were alleviated.

Six years later, in early 1987, he again developed symptoms of malaise, muscle cramps, and pruritus. The serum calcium level was $10.0 \mathrm{mg} / \mathrm{dl}$, with a PTH level of $690 \mathrm{pg} / \mathrm{ml}$. A second cervical exploration identified an enlarged left inferior parathyroid gland remnant, which was excised and a $60 \mathrm{mg}$ portion autotransplanted into the right brachioradialis muscle. He experienced transient relief, but his symptoms soon recurred. The serum calcium level was $9.1 \mathrm{mg} / \mathrm{dl}$ when his PTH level was $509 \mathrm{pg} / \mathrm{ml}$. Computed tomography (CT) of the neck revealed two small nodules next to 
the left jugular vein, which were thought to be consistent with lymph nodes. A sestamibi scan was negative. Selective venous PTH levels in blood obtained from each arm were $500 \mathrm{pg} / \mathrm{ml}$ on the left and $1400 \mathrm{pg} / \mathrm{ml}$ on the right. Hyperfunctioning parathyroid tissue previously implanted in the right arm was suspected. An exploration of the right forearm with excision of the suspected parathyroid implant revealed no residual parathyroid tissue.

Despite an intervening successful renal transplant, persistent hyperparathyroidism caused derangements in his general metabolism and end-organ damage involving bones and joints. Laboratory evaluation continued to show elevated PTH levels, ranging from 250 to $400 \mathrm{pg} / \mathrm{ml}$. Noninvasive imaging studies were negative. Therefore selective venous sampling was undertaken. Marked elevations of PTH (2000-4600 pg/ml) were identified high in the internal jugular vein on the left side.

The patient was reexplored in 1996 via a lateral approach. Just below the level of the carotid bifurcation, within the carotid sheath, there was a $1.0 \times 1.2 \mathrm{~cm}$ mass enveloped by fibers of the vagus nerve. The mass was carefully dissected from the vagal trunk, sacrificing only a few of its fibers. Histopathologic studies revealed a hypercellular parathyroid gland without histologic features of malignancy. Its weight was $660 \mathrm{mg}$. Postoperatively the patient had no dysphonia or dysphagia, so postoperative laryngoscopy was not performed. Initially he was placed on calcitriol and calcium carbonate. He has remained asymptomatic. His calcium level is $9.7 \mathrm{mg} / \mathrm{dl}$ and the PTH $41 \mathrm{pg} / \mathrm{ml}$.

\section{Patient 2}

A 43-year-old man was initially evaluated and explored for primary hyperparathyroidism at an outside hospital. The patient had had a 20-year history of nephrolithiasis. He also had hypertension with diastolic pressures $>100 \mathrm{mmHg}$; and he had complained of progressive fatigue, forgetfulness, and occasional abdominal discomfort. A serum calcium level was $12.3 \mathrm{mg} / \mathrm{dl}$ with an intact PTH level of $98 \mathrm{pg} / \mathrm{ml}$. A sestamibi scan showed no abnormality. Because of the patient's significant hypertension, a workup for pheochromocytoma was performed and was negative. His initial neck exploration identified four parathyroid glands. The left superior and inferior parathyroid glands were biopsied and interpreted to be normocellular. The right parathyroid glands were more difficult to locate. A right thyroid lobectomy and thymectomy were performed. Histopathologic studies revealed a normocellular inferior parathyroid gland within the thymus and a partially intrathyroidal hypercellular superior gland. Postoperatively, the patient's calcium and PTH levels remained elevated at $12.3 \mathrm{mg} / \mathrm{dl}$ and 117 $\mathrm{pg} / \mathrm{ml}$, respectively. He was referred to the University of Michigan Medical Center because of a suspected mediastinal fifth gland. A repeat sestamibi scan was negative. Selective venous sampling identified high levels of PTH $(3832 \mathrm{pg} / \mathrm{ml})$ in the effluent of the left superior thyroid vein. Subsequent ultrasonography of the left upper neck identified a $1.4 \mathrm{~cm}$ mass between the carotid and the internal jugular vein.

The patient underwent repeat neck exploration through a lateral approach. Just below the carotid bifurcation a $1.4 \mathrm{~cm}$ bulge was noted within the fibers of the vagus nerve. With careful dissection this mass was freed from the vagus nerve, sparing all but a few nerve fibers that were adherent to the parathyroid adenoma (Fig. 1). Histopathologic studies revealed a hypercellu-

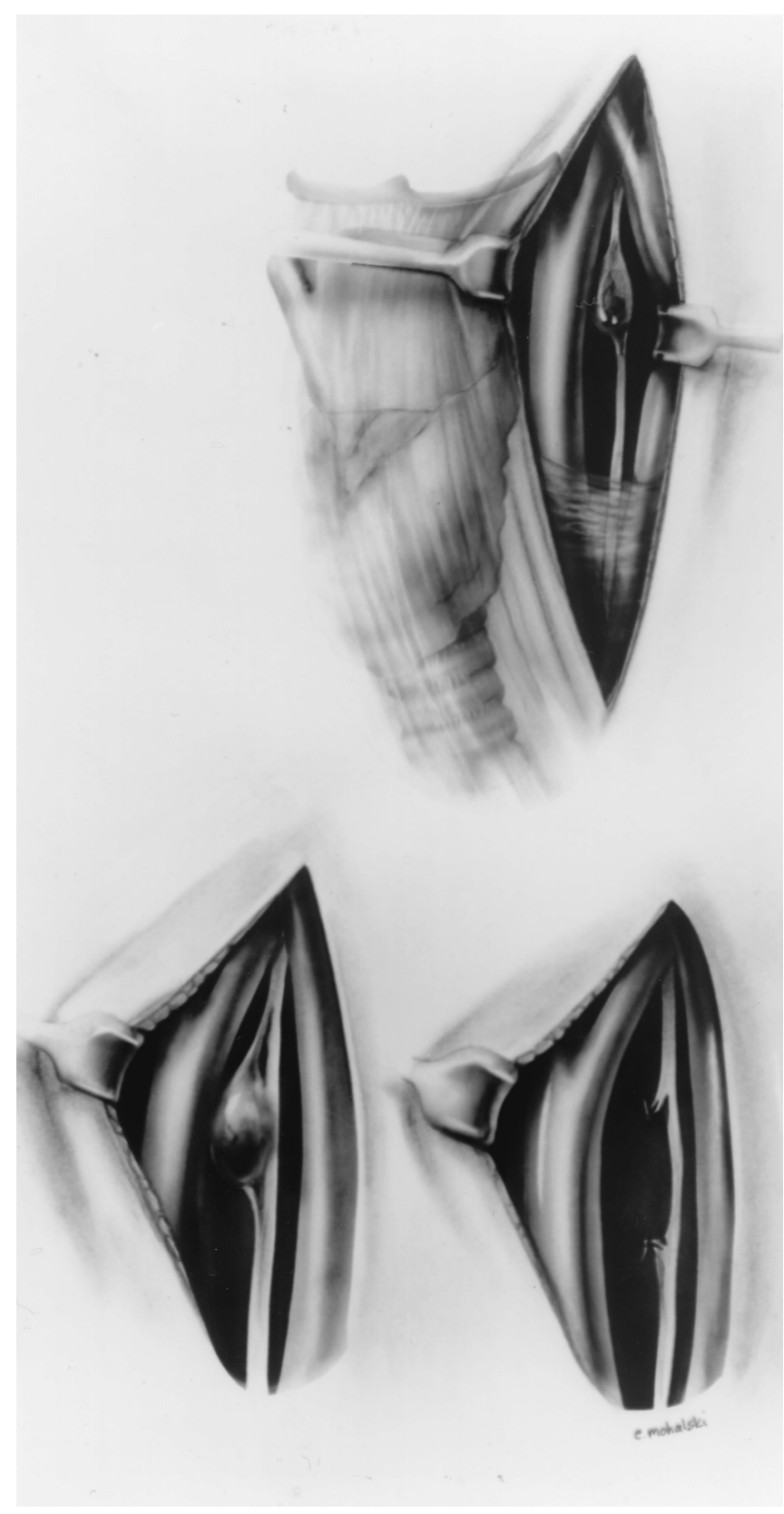

Fig. 1. Left intravagal supernumerary parathyroid adenoma (case 2). Note that several vagal nerve fibers coursed through the $1.4 \mathrm{~cm}$ adenoma, whereas others were firmly adherent and carefully freed from its capsule. The adenoma was $1 \mathrm{~cm}$ below the level of the carotid bifurcation.

lar parathyroid gland intimately associated with vagal fibers (Fig. 2). The parathyroid mass was free of mitoses and fibrous bands, consistent with a diagnosis of adenoma.

Postoperatively, the patient's ionized calcium level rapidly normalized to $5.0 \mathrm{mg} / \mathrm{dl}(4.6-5.4 \mathrm{mg} / \mathrm{dl})$. Three days after the operation the patient noted some difficulty swallowing and hoarseness. Laryngoscopic examination demonstrated a left vocal cord paresis, without complete paralysis; it recovered spontaneously within 3 months. He continues to be maintained on calcium carbonate and is otherwise asymptomatic. 




Fig. 2. Hypercellular parathyroid tissue (A) intimately associated with the vagal nerve fiber and its capsule (B). Mitosis and fibrous bands are absent in the parathyroid mass. A single nerve bundle coursing in the parathyroid tumor was sacrificed, but more than $95 \%$ of the vagus nerve was left intact. (Hematoxylin-eosin, $\times 82.5$ )

\section{Discussion}

Anomalies in the location of the parathyroid glands, especially inferior glands, are not rare. Their variable locations in relation to the thyroid gland and other structures of the neck and mediastinum are well recognized. Finding functional parathyroid tissue within the vagus nerve is exceptionally rare, however. Review of the English literature reveals only three previous cases (Table 1). Reiling et al. in 1972 described a 55-year-old woman with persistent hyperparathyroidism who had a $0.5 \times 0.8 \mathrm{~cm}$ parathyroid adenoma enucleated from her vagus nerve [6]. In 1989 Takimoto et al. reported a 79-year-old woman with a $1.7 \times 2.0 \mathrm{~cm}$ painless mass in the left anterior cervical triangle [7]. CT scans suggested a neurinoma (neurilemoma) of the left vagus nerve. PTH and calcium levels, however, were both elevated. On exploration, five parathyroid glands were identified: Four were normal, and there was one adenoma, which was shelled out of the vagus nerve. In 1994 Doppman et al. reported a 40-year-old woman who had undergone four previous unsuccessful operations [8]. Venous sampling localized the abnormal secretion from high in the right side of the neck. A $1.2 \times 0.8 \mathrm{~cm}$ adenoma, completely enveloped by the vagus nerve, was enucleated. Postoperatively, hypercalcemia resolved in all three of these patients.

An embryologic explanation for ectopic parathyroid tissue within the vagus nerve was initially described by Gilmour in 1937 [9]. In dissections of stillborn infants, Gilmour found accessory parathyroid tissue within the ganglion of the vagus nerve. The third branchial pouch, which gives rise to the inferior parathyroid glands, was found to be in direct relation to the ectodermal structures, particularly the vagus nerve, in the fetuses he examined. He suggested that intravagal parathyroid tissue arising from the third branchial pouch may split off and become embedded in or adjacent to the vagus during embryogenesis. He postulated that it could give rise to ectopic or supernumerary parathyroid tissue. More recently, Lack et al. (1988) provided further evidence of ectopic parathyroid tissue associated with the vagus nerve. In a postmortem study of 64 vagus nerves from 32 children under the age of 1 year, $6 \%$ of the vagus nerves contained parathyroid chief cells located either adjacent to epineurium or perineurium or as a discrete aggregate of cells within the substance of the nerve [10]. Finding parathyroid tissue in these locations was confirmed by immunostaining for chromogranin and PTH. As did Gilmour, Lack et al. postulated that this microscopic parathyroid tissue probably represented accessory or supernumerary tissue.

Persistent hyperparathyroidism occurs in $2 \%$ to $5 \%$ of patients after exploration by an experienced surgeon [11]. Reported success rates of reoperation for hyperparathyroidism have ranged from $65 \%$ to $90 \%$ [3, 12-14]. Unsuccessful treatment of persistent hyperparathyroidism can be attributed to failure to identify and completely resect abnormal parathyroid tissue, whether it is an ectopic inferior or superior gland or a possible supernumerary gland. Most commonly, failure of reoperation is the result of a single diseased gland remaining in the neck or mediastinum. Undescended parathyroid adenomas comprise a significant proportion (9\%) of adenomas during reoperation for persistent hyperparathyroidism [15]. Although an undescended parathyroid adenoma must always be considered a possibility in reoperative cases, its occurrence should be suspected at the initial exploration when three normal glands have been found and an adenoma remains undetected. If an inferior gland is missing, in addition to exploring the ipsilateral thymus and lower pole of the thyroid the carotid sheath must be opened and explored to the level of the carotid bifurcation. When a superior gland adenoma has not been detected after a diligent search in its usual locations, including the posterior mediastinum, attention should be directed to the pharyngeal wall above the level of the superior pole of the thyroid. The rare undescended superior gland has been found most commonly at the level of the piriform sinus in approximation to or within the pharyngeal wall [5]. Neither of these situations is directly relevant to the occurrence of intravagal hyperplastic glands, which have been supernumerary in all cases. Although an intravagal parathyroid gland may be embryologically derived from the third branchial pouch, it is not analogous to the well recognized parathymus gland or undescended inferior gland. With primary hyperparathyroidism, a possible intravagal gland should be considered when four normal glands have been found and a cervical thymectomy (the most common location for a supernumerary gland) fails to reveal an adenoma. Before completing the neck exploration with the assumption that the patient has a deep mediastinal adenoma, the carotid sheaths should be opened and the vagus nerves explored. With secondary and tertiary hyperparathyroidism, as in case 1, a hyperfunctioning supernumerary gland is likely only after there is biochemical evidence of persistent disease following an apparently successful subtotal or total parathyroidectomy.

Both of our patients had histories of failed previous neck explorations. In one patient, four past surgical attempts had been made to correct persistent hyperparathyroidism. Successful surgical intervention in each case was guided by selective venous sampling localization. At operation, both adenomas were located in the vagus nerve and represented supernumerary or accessory tissue. Each adenoma was at a level below vagal ganglions and was several centimeters below the carotid bifurcation. This is consistent with what would be expected based on the work of Gilmour and Lack et al.

Exploration for hyperparathyroidism requires a complete, meticulous surgical dissection to identify all parathyroid glands and to search for possible accessory tissue in selected cases. Although 
Table 1. Reported intravagal parathyroid adenomas.



US: ultrasonography; CT: computed tomography; MRI: magnetic resonance imaging; NA: not available.

${ }^{a} \mathrm{~N}$, neck; M, mediastinum; A, arm exploration.

${ }^{b}$ Normal calcium level $8.8-10 \mathrm{mg} / \mathrm{dl}$.

${ }^{c}$ Normal calcium level $4.3-5.8 \mathrm{mEq} / \mathrm{L}$.

${ }^{d}$ Normal calcium level $2.05-2.50 \mathrm{mmol} / \mathrm{L}$.

${ }^{e}$ Normal parathyroid hormone level $0.20-1.00 \mathrm{ng} / \mathrm{ml}$.

${ }^{f}$ Normal parathyroid hormone level $10-65 \mathrm{pg} / \mathrm{ml}$.

rare, intravagal parathyroid adenomas, as we have described, do occur. These cases emphasize the need for meticulous exploration of all potential parathyroid sites in the neck when a diseased supernumerary gland is suspected. In all five cases described to date, the intravagal parathyroid tissue was supernumerary. Examination of the vagus nerve should be considered when four normal glands are found, as intravagal adenomas appear to represent accessory ectopically located parathyroid tissue.

When an intravagal parathyroid adenoma or hyperplastic gland has been identified, great care should be taken during its excision. With gentle, meticulous technique, the intact gland can usually be separated from the nerve fibers, preserving their function. Our second case was apparently exceptional in that a few fibers had to be sacrificed because of their course directly through the tumor. Although transient recurrent laryngeal nerve paresis has resulted in these cases, complete recovery can be anticipated when care is taken during the procedure.

\section{Résumé}

Les adénomes parathyroïdiens à l'intérieur des nerfs vagues sont exceptionnels: seulement trois cas ont été rapportés dans la littérature Anglo-Saxonne. Les objectifs de cet article sont de décrire deux cas supplémentaires de patients ayant une glande parathyroïde hyperactive, retrouvée à l'intérieur du nerf vague, et de définir leur anatomie. Les deux patients avaient une histoire d'hyperparathyroïdie persistante en dépit de plusieurs interventions chirurgicales à visée thérapeutique. On a objectivé une localisation cervicale haute dans les deux cas par des échantillons veineux électifs. Chez chaque patient, on a réussi à enlever la glande parathyroïde localisée à l'intérieur du nerf vague avec, par la suite, une résolution des taux de calcium et de parathormone. Chaque adénome se trouvait à l'intérieur du nerf vague au-dessous du niveau de la bifurcation de la carotide et a pu être énucléé sans sacrifice du nerf. Dans notre cas, comme dans ceux rapportés auparavant, il s'agissait de glandes surnuméraires, représentant du tissu parathyroïde dérivé de la troisième poche embryonnaire. L'exploration de l'hyperparathyroïdie nécessite une dissection complète et méticuleuse pour identifier toutes les glandes parathyroïdes et, dans certains cas, pour rechercher du tissu glandulaire accessoire. Notre expérience ainsi que la revue de la littérature, montre que bien qu'extrêmement rare, les adénomes de la parathyroïde intravagaux existent. Lorsqu'on retrouve quatre glandes normales à l'exploration du cou pour hyperparathyroïdie, on recommande d'examiner les nerfs vagues car les adénomes intravagaux représentent du tissu parathyroïde accessoire ectopique.

\section{Resumen}

Los adenomas paratiroideos intravagales son excepcionalmente raros, con sólo tres casos informados en la literatura. Nuestro propósito es describir dos pacientes adicionales con glándulas paratiroides hiperfuncionantes ubicadas en la sustancia del nervio vago y definir la anatomía de este hallazgo. Los dos pacientes presentaban historia de hiperparatiroidismo persistente a pesar de múltiples intervenciones terapéuticas. En ambos casos se detectó una localización cervical alta mediante muestreo venoso, y en cada uno de ellos se logró la resección exitosa de una paratiroides intravagal con la consiguiente resolución de los niveles de calcio y parathormona. Los dos adenomas estaban ubicados en la sustancia del nervio vago por debajo de la bifurcación carotídea y fueron enucleados sin sacrificar el nervio. En nuestros dos casos, como en los informados previamente, las paratiroides eran supernumerarias, representando tejido paratiroideo embriológicamente derivado de la tercera bolsa branquial. La exploración por hiperparatiroidismo requiere una disección quirúrgica completa y meticulosa para identificar todas las glándulas paratiroides y para buscar tejido accesorio en casos seleccionados. Nuestra experiencia, así como la revisión de la literatura, sirve para hacer énfasis en que a pesar de ser extremadamente raros, los adenomas paratiroideos intravagales 
ocurren en la práctica médica. El examen del nervio vago debe ser, por consiguiente, considerado cuando ya se han encontrado cuatro glándulas en la exploración quirúrgica, puesto que los adenomas intravagales parecen representar tejido paratiroideo accesorio ectópicamente ubicado.

\section{References}

1. Thompson, N.W., Eckhauser, F., Harness, J.: Anatomy of primary hyperparathyroid surgery. Surgery 92:814, 1982

2. Beahrs, O.H., Edis, A.E., Purnell, D.C.: Unusual problems in parathyroid surgery. Am. J. Surg. 134:502, 1977

3. Wang, C.A.: Parathyroid re-exploration: a clinical and pathological study of 112 cases. Ann. Surg. 186:140, 1977

4. Jaskowiak, N., Norton, J.A., Alexander, H.R., Doppman, J.L., Shawker, T., Skarulis, M., Marx, S., Spiegel, A., Fraker, D.L.: A prospective trial evaluating a standard approach to reoperation for missed parathyroid adenoma. Ann. Surg. 224:308, 1996

5. Simeone, D., Thompson, N.W., Sandelin, K.: Undescended superior parathyroid gland: a potential cause of failed cervical exploration. Surgery 118:949, 1995

6. Reiling, R.B., Cady, B., Clerkin, E.P.: Aberrant parathyroid adenoma within vagus nerve. Lahey Clin. Bull. 21:158, 1972
7. Takimoto, T., Okabe, Y., Ito, M., Umeda, R.: Intravagal parathyroid adenoma. J. Laryngol. Otol. 103:704, 1989

8. Doppman, J.L., Shawker, T.H., Fraker, D.L., Alexander, H.R., Skarulis, M.C., Lack, E.E., Spiegel, A.M.: Parathyroid adenoma within the vagus nerve. A.J.R. 163:943, 1994

9. Gilmour, J.R.: The embryology of the parathyroid glands, the thymus and certain associated rudiments. J. Pathol. Bacteriol. 45:507, 1937

10. Lack, E.E., Delay, S., Linnoila, R.I.: Ectopic parathyroid tissue within the vagus nerve: incidence and possible clinical significance. Arch. Pathol. Lab. Med. 112:304, 1988

11. Satava, R.M., Jr., Beahrs, O.H., Scholz, D.A.: Success rate of cervical exploration for hyperparathyroidism. Arch. Surg. 110:625, 1975

12. Grant, C.S., van Heerden, J.A., Charboneau, J.W., James, E.M., Reading, C.C.: Clinical management of persistent and/or recurrent primary hyperparathyroidism. World J. Surg. 10:555, 1986

13. Levin, K.E., Gooding, G.A.W., Okerlund, M., Higgins, C.G., Norman, D., Newton, T.H., Duh, Q.Y., Arnard, C.D., Siperstein, A.E., Zerg, Q.H., Clark, O.H.: Localizing studies in patients with persistent or recurrent hyperparathyroidism. Surgery 102:917, 1987

14. Beazley, R.M., Costa, J., Ketcham, A.S.: Reoperative parathyroid surgery. Am. J. Surg. 130:427, 1975

15. Fraker, D.L., Doppman, J.L., Shawker, T.H., Marx, S.J., Spiegel, A.M., Norton, J.A.: Undescended parathyroid adenoma: an important etiology for failed operations for primary hyperparathyroidism. World J. Surg. 14:342, 1990 